\title{
What is your corporate brand worth? A guide to brand valuation approaches
}

\author{
J. Reyneke ${ }^{a}$, R. Abratt ${ }^{\mathrm{ab} *}$ and G. Bick ${ }^{\mathrm{c}}$ \\ ${ }^{2}$ Graduate Researcher, Wits Business School, University of the Witwatersrand, P O Box 98, Wits, South Africa 2050. \\ brofessor of Marketing, Huizenga Business School, Nova Southeastern University, 3301 College Avenue, Fort Lauderdale, FL33314 \\ 'Professor of Marketing, Graduate School of Business, University of Cape Town, Portswood Rd, Greenpoint, Cape Town 8001 \\ *To whom all correspondence should be addressed \\ abratt@nova.edu
}

\begin{abstract}
Brand league tabies are becoming very popular as a reflection of the performance of an organisation. Stakeholders also view the ranking of brands as an important yardstick when forming a brand image. This article reviews the available approaches to brand valuation. The research followed a case study methodology. The case site that was used for this study was The South African Gold Coin Exchange. The main objective of this study was to calculate the value of the corporate brand of one company using different methods. The aim was to show that the value of the brand is highly dependent on the method used. In total twelve senior managers and directors were interviewed. It then calculates the value of the South African Gold Coin Exchange Brand using a number of different models. There is a different result under each approach. It has been established that different models are more appropriate than others depending on the manager's valuation objectives. This research is a single case study and therefore future research should have an increased sample size and be a cross industry study, Managers are often confronted with the problem of deciding which valuation method to use as there are many alternative approaches. We provide guidance for managers who want to perform a brand valuation of their organisation.
\end{abstract}

\section{Introduction}

Ranking of brands and the publication of league tables has become a popular yardstick for consumers, investors and other stakeholders when forming a brand image about the 'best' brands. Many organisations have seen their brands grow in value to become a substantial asset, with brand valuation being used not only to measure the value of the brand in question but also as a performance metric (Raggio $\&$ Leone, 2009). The problem with these league tables is that they often produce different scores and valuations, leading to confusion and scepticism amongst different groups of stakeholders. Certain valuation approaches, however, may be appropriate for certain brand equity valuation objectives but not for others (Salinas \& Ambler, 2009). Managers face the problem of not knowing which brand valuation method is appropriate to use. Although the different brand valuations are well documented, a gap exists in the literature with regard to performing a brand valuation of an organisation using different methods (see among others Seetharaman, Bin Mohd Nadzir \& Gunalan, 2001). Each valuation method is more suitable to achieve specific objectives which can vary according to organisational needs. The main objective of this study was to calculate the value of the corporate brand of one company using different methods. The aim was to show that the value of the brand is highly dependent on the method used. Another purpose of this study was to investigate how to select a brand valuation approach to meet specific brand valuation objectives. We first discuss the resource-based theory of the firm in relation to brands, and then highlight the importance of the corporate brand as a valuable resource to the organisation. We also review all the available brand valuation methods. These are then used to calculate the brand value of The South African Gold Coin Exchange. (http://www.sagoldeoin.co.za/).

\section{Resource-based theory of the firm}

The resource-based theory of the firm suggests that a firm is able to develop a sustainable competitive advantage by strategically exploiting its strengths and opportunities while minimising its weaknesses and threats (Barney, 1991). A brand name is a resource that fits the criteria of the resourcebased view (Christensen, Fahey \& Srivastava, 2001). Resources, as assets that a firm uses, can and should be allocated to differentiate the organisation in its industry or environment and thereby provide a differential advantage to the organisation (Barney, 1991).

The resource-based view theorises that, in a firm, resources which are heterogeneous, immobile and that provide empirical indicators such as value, rareness, imitability and substitutability, have the ability to provide a sustainable competitive advantage (Barney, 1991). As a resource, a brand's ability to fulfil these criteria is reiterated by Balmer \& Gray (2003). They are of the opinion that a strong wellmanaged corporate brand qualifies as a sustained valuable resource. By differentiating a firm's products and providing confidence to consumers, brands are being recognised as adding value and contributing to the strengths of 
organisations (Doyle, 2001). The resource-based theory provides a model of how firms create value and how brands can add to that value (Doyle, 2001).

\section{The importance of corporate brands}

"The corporate brand defines the firm that will deliver and stand behind the offering that the consumer will buy and use." (Aaker, 2004: 6). Through this statement, Aaker (2004) suggests that the corporate brand is the representation of the firm, its products and the experiences associated with their usage. He adds that the corporate brand is flexible and able to play different roles within the brand portfolio (Aaker, 2004). The corporate brand is able to play multiple roles whereby stakeholders use it as a navigational tool, denoting ownership, representing the image of the organisation, being a symbol associated with key values of the organisation, a way to construct individual identities (differentiation) and, finally, a conduit for pleasurable experiences (Balmer \& Gray, 2003). Brands are increasing in importance due to their internal value and the power that they have to influence customer perceptions of organisations (Narayan, 2012). Balmer and Gray (2003) suggest that a corporate brand provides an overarching level of trust between stakeholders and the organisation. They comment that the level of trust is transferred to new product lines and even to diversified products and services when entering new markets. The ability of the corporate brand to transfer its characteristics stems, in part, from the associations and expectations that stakeholders have of the brand due to their interactions with it. Whether negative, positive or neutral associations, stakeholders form feelings and thoughts about the brand and expect similar experiences in future engagements (Leiser, 2004). The association with, and expectation of, a corporate brand by stakeholders adds value to an organisation, product or services and builds corporate brand equity (Shamma \& Hassan, 2011). Smith, Smith and Wang (2010) found that a positive brand image provides organisations with the opportunity to derive a market premium benefit. Their studies also found that not only does positive brand image lead to a higher market value premium but it also leads to better financial performance and a lower cost of capital. The value of brands is further illustrated by the high prices that are paid for brands when traded in mergers and acquisitions. These transactions provide evidence of the acceptance of the corporate brand as a valuable asset to the organisation (M'Zungu, Merrilees \& Miller, 2010).

Brand equity has an impact on a customer's profitability and the customer's lifetime value. As a customer's lifetime value increases so do the returns for the firm (Heitmann, Lehmann, Neslin \& Stahl, 2012). Gerzema (2009) and Heitmann et al. (2012) suggest that the customers' perception of the corporate brand has the ability to inform their perception of the potential and profitability of an organisation. The corporate brand can shape both external perceptions and behaviour and employee perceptions and behaviour. The corporate brand not only focuses on customers and, through aligning the communications, values and culture of an organisation with the commitments made to employees, it has the ability to shape employee behaviours (Brownhill, 2012; Harris \& de Chernatony (2001).

\section{Brand equity objectives}

Brand equity can make up a significant portion of an organisation's market capitalization. Brand equity valuation objectives can be grouped into three categories namely: valuations for accounting purposes; valuation for transactional purposes; and valuations for strategic brand management purposes (Salinas, 2009). Brands on the balance sheet or accounting for brands as a concept has been around since the late $1980 \mathrm{~s}$ and is a relatively new accounting practice (Otonkue, Edu \& Ezak, 2010). With managers increasingly under pressure to provide shareholder value, including intangible assets on the balance sheet has become a more popular practice (Bick, 2009; Salinas \& Ambler, 2009). In a study conducted by Fortune magazine where 3,500 US companies were surveyed, intangible assets accounted for $72 \%$ of a company's market value with $40 \%$ to $70 \%$ of that potentially contributable to brands (Yeung \& Ramasamy, 2008).

Organisations see brands as enormously valuable pieces of property that can be legally registered as a trademark that has the ability to influence consumer behaviour which can provide security for future revenues and be bought and sold. Large earnings multipliers have been applied to brands during mergers and acquisitions or when brands were bought or sold (Kotler \& Keller, 2009). Salinas (2009) identifies two types of transactions where brand valuations will be useful. These are internal and external transactions. Each contains two subcategories: securitization and tax planning as subcategories for internal transactions; and acquisitions and mergers for external transactions. Brand equity valuation has been used as a management tool in certain instances and can be used to compare the levels of success of different brands, to inform brand architecture and brand extension decisions, and to measure the return on investment of marketing expenditure (Salinas, 2009).

Building a strong brand has become an important objective for companies because of the notion that strong brands provide their owners with a competitive advantage (Amini, Darani, Afshani \& Amini, 2012). To extract the optimal benefit from the information that brand equity calculation can provide, organisations need to look even further into how brand equity can be leveraged to meet business goals (Leiser, 2004). This would require an understanding of the components that form part of the brand equity calculation and how these components align to the business goals and objectives.

\section{Brand equity valuation approaches}

The current literature on brand valuation methods and models is vast. They tend to be grouped in different ways. Virvilaitè and Jucaitytè (2008) group brand valuation 
models together in terms of common use, proposing the following three groupings: Traditional economic brand valuation models; Psychographic and behaviourally orientated models; and Composite economic - behavioural orientated models. Abratt and Bick (2003) grouped their review of the brand valuation approaches into five categories: Cost-based approaches; Market-based approaches; Economic use or income-based approaches; Formulary approaches; and Special situation approaches. The cost-based approaches consider the costs incurred to create the brand or, should the brand be replaced, what the costs would be (Abratt \& Bick, 2003). The reliability of cost measurement of brands is discussed by Otonkue et al. (2010) who suggest that the accounting policy in terms of brand recognition and cost measurement depends on the way that the brand has been acquired. Salinas and Ambler(2009) suggest a market-based approach, where transactions involving brands in similar markets are compared to determine an open market value, and is probably the most reliable approach. This approach is very useful when one wants to sell the brand (Abratt \& Bick, 2003). Economic use or income-based approaches use the future net earnings contributed by the brand and considers the value in the current time (Abratt \& Bick, 2003). Salinas and Ambler (2009) suggest that the income-based approach is a valuable tool should the user be concerned about share price fluctuation and the organisation's reputation in the financial markets. Formulary approaches use multiple criteria and are categorized together due to their popularity by the commercial sector (Abratt \& Bick, 2003). Baumann, Gray and Mirzaei (2011) identify a host of formulary brand equity valuation models used in the commercial sector and question their subjective intangible measures as opposed to objective behavioural metrics.

Prior research leads us to conclude that the different brand valuation approaches can be classified as either economic based, behavioural based, combined economic and behavioural based and formulary approaches. These will now be discussed.

\section{Economic based approaches}

The first model is the Capital market-orientated brand valuation. In many sales environments (including the stock market one can argue, as per the theory of markets), the product, item or company is worth the maximum amount that someone is prepared to pay for it (Virvilaite \& Jucaityte, 2008). This would include value added from both tangible and intangible assets, such as brand equity, where intangible assets augment the value provided by tangible assets (Simon \& Sullivan, 1993). The capital marketorientated brand valuation model uses the company's market capitalization value, subtracts all tangible assets and other known intangible assets (except brand value, should it already be on the balance sheet), and the remaining margin is attributed to brand value. The brand value is thus defined as the present value of future cash flows attributed to the brand (Simon \& Sullivan, 1993). If the company has more than one brand it is calculated pro rata as per each brand's contribution to revenues (Virvilaité \& Jucaitytè, 2008).

The second model is the Market value-orientated brand valuation method which requires a marketer to determine the fair market price of the brand by comparing it to similar brands in the market place (Virvilaite \& Jucaityté, 2008). The third model is the cost-oriented brand valuation (residual value according to the investment theory). This method is underpinned by the net asset value approach where the assets are listed by expenses and engagements subtracted to provide a "net" value for the asset (Virvilaite and Jucaityte, 2008). The fourth model is the Earnings capacity-oriented brand valuation (Kern's earnings capacity model). It uses the future cash flows attributable to the brand and discounts them back to a present value using a set interest rate (Virvilaite \& Jucaityte, 2008). The fifth is the Customer-oriented brand valuation model. It works on the premise that customers form relationships with brands and as a result of the relationship, repeat purchases do not require new purchasing decisions. The average customer spend is used together with a rate of churn to determine future earnings (Virvilaité \& Jucaityté, 2008). They summarize this grouping as being skewed towards material brand value and is one which does not take the customers' influence on brand value into consideration.

The sixth model is the Accumulated cost model which uses historical marketing costs to derive a value for the brand. The primary difficulty with this model is determining which costs should be included as part of the marketing spend. One of its advantages, though, is that the historical costs are known (Abratt \& Bick, 2003). The seventh model is the replacement cost based on launching a new brand. Abratt and Bick (2003) comment that this is one of the most difficult models to calculate. They cite Aaker's (1991) proposition that the cost of launching a brand is divided by the chances of success. This notion, however, does not take into consideration first mover advantage, versus the success of existing brands. The eighth is using a conversion model. This model uses the premise that the brand value is the level of awareness required to generate the current level of sales (Abratt \& Bick, 2003). One of the challenges of this model as identified by Abratt and Bick (2003) is that it does not allow for change in consumer behaviour. It also assumes that awareness guarantees purchase. The ninth model is the Consumer preference model. This model is based on Aaker's (1991) premise that the increase in brand awareness compared to the increase in share price over the same period, can be used to calculate the brand value. One of the challenges of this model is to ascertain how much of the increase in share price is directly linked to the increase in awareness. Abratt and Bick (2003) also highlight the issue that one would not expect the two variables to have a linear ratio.

The tenth is the Comparable approach. This model - as the name would suggest - uses comparable brands that have been sold at a premium to derive a multiple that can be applied to the brands being valued. One of the advantages, as highlighted by Abratt and Bick (2003), is that the 
multiple is based on what the market is actually willing to pay for similar brands. One of the difficulties is to find two brands that are alike to be able to make a fair comparison. The eleventh is the use of real options. In this model the brand value is the value of the underlying asset. The cost of developing the brand is the exercise price. To calculate the value using this model, Abratt and Bick (2003) note that the following elements are required: risk free rate, implied volatility of the underlying asset, and expiration time. Abratt and Bick (2003) add that the practical application of this model is very difficult. The twelfth model is the residual method. This model derives the brand value by subtracting the net asset value from the market capitalisation. The "residual" value can be attributed to intangible assets of which the brand is one. Abratt and Bick (2003) highlight two key assumptions in this model, namely that the market is efficient, and that the assets are being used to their full potential.

The thirteenth is the Royalty relief method. This model determines brand value based on the royalty that a company would have to pay to use the brand if it had to license it (Aaker, 1991). Abratt and Bick (2003) note that the challenge of this model is to determine the correct royalty rate. They suggest that as a rule of thumb $25 \%$ of the net profit or $5 \%$ of the turnover should be used. The fourteenth is the Price premium. It is based on the premise that a branded product can charge a premium compared to a nonbranded product (Aaker, 1991). The model thus discounts future sales premiums to a present value. The fifteenth is Conjoint analysis. The conjoint analysis calculates the brand value as the discounted potential future revenues of customers (Abratt \& Bick, 2003). This model determines the value of the brand attribute through market research to determine future values. The sixteenth is the differences between return on investment, return on assets and economic value added. This is very similar to conjoint analysis in terms of its approach, and encompasses three models in one, each using a different base. The premise, similar to that of price premium and conjoint analysis, is that branded products command a price premium and that if we calculate the future premiums we would have calculated the brand value (Aaker, 1991). Abratt and Bick (2003) note that the models do not make the distinction between intangible assets and where exactly the premium is derived from. The seventeenth is the Price-to-sales ratio model. Using the price-to-sales ratio of a branded firm and that of a nonbranded firm the difference in value would provide the brand value (Abratt \& Bick, 2003). It is difficult to find two firms that are the same except for their branding differences and no allowance is made in this model for value being possibly derived from other differences. The eighteenth is the Future earnings model. This model uses future profits derived from the brand and discounts them back. It is very difficult, however, to determine what portion of the estimated future profits are attributable to the brand and this model does not allow for any balance sheet anomalies (Abratt \& Bick, 2003). The nineteenth is the discounted cash flow model. Similarly determining what portion of future cash flows are attributable to the brand proves to be problematic, and even though this model takes balance sheet and accounting anomalies into account, if one used free cash flows allocating the correct cash flows is difficult (Abratt \& Bick, 2003).

\section{Behavioural based approaches}

The first model under this grouping is the Aaker brand valuation model. Aaker (1991) defines brand loyalty, brand awareness, perceived quality, brand associations and other proprietary brand assets as elements that create brand equity. According to his model these elements provide value to customers by enhancing their product satisfaction and their confidence in the purchasing decision. It also provides value to the firm by improving marketing programme efficiency, leverage in the trade, margins, brand extensions and competitive advantage. Virvilaitė and Jucaityté (2008) criticize this model because it lacks quantifiable value and because the psychographic attributes are not converted into a representative monetary value.

The second model is the Kapferer brand valuation model. This model suggests that the relationship between a customer and a brand is based on a trade-off where the brand provides reassurance and the customer provides repeat purchase. As such he concludes that the stronger the brand value the less the customer-purchasing risk. The lower the risk to the customer the less the need for the brand to differentiate the product (Kapferer, 1997). Virvilaité and Jucaityte (2008) critique the model for not being dynamic enough to allow changes in factors such as customer values and competitive strategies which affect brand value, according to this model.

The third is the Keller brand valuation model. The true future value of brands is in the minds and actions of consumers. Through their purchasing decisions, they decide which brands have more brand equity than others (Kotler \& Keller, 2009). Keller (2013) defines brand value as the difference brand knowledge makes in the customers' decision-making. Brand knowledge comprises brand awareness (recall and recognition) and brand image. The focus of his grouping is the attitudes and behaviour of customers (Virvilaitè \& Jucaitytè, 2008).

\section{Combined economic and behavioural based approaches}

The first major model under this grouping is the integrated model of Virvilaitè and Jucaityte (2008). They developed an integrated brand valuation model which seeks a balance between the traditional company-based view and the customer-based aspects. The one side of this model is dedicated to the brand value from the customers' point of view and uses Aaker's (1991) brand valuation model to measure the value. Each element is rated on a scale between zero and 20 and then added together to provide a point score out of 100 . On the other side of the model, is the brand value from the company's point of view. Financial asset factors are excluded from the calculation to receive a net brand financial value. Financial strength factors are then used to 
derive the points for the company-based brand value. The customer-based viewpoints are added to the company-based viewpoints to provide a total point based brand value.

The second model is the Swiss based International Organisation of Standards (ISO) 10668. In an attempt to provide consistency, they issued a new standard pertaining to brand valuation - ISO 10668. "The new standard provides consistent, reliable procedures and methods for measuring brand values..." (Catty, 2011:1) Eight underlying themes are evident in the standard and include transparency, validity, reliability sufficiency, objectivity, parameters and purpose, all of which are currently best practice standards (Catty, 2011).

\section{Formulary based approaches}

Formulary approaches use multiple criteria and are categorized together due to their popularity by the commercial sector (Abratt \& Bick, 2003). Baumann et al. (2011) identify a host of formulary brand equity valuation models used in the commercial sector and question their subjective intangible measures as opposed to objective behavioural metrics. Models under this category include: the Interbrand approach (Interbrand.com); and the BrandZ method (http://www.millwardbrown.com/BrandZ). The Interbrand approach is based on the assessment of what the value is today of the earnings the brand can be expected to generate in the future. It takes into account the ways in which a brand benefits the organisation; including the attracting and retaining talent and delivering on customer expectations (Keller, 2013). The BrandZ valuation methodology combines extensive and ongoing consumer research with rigorous financial analysis (https://www.millwardbrown.com/BrandZ/Top_100_Global Brands/Methodology.aspx). It is not our intention to discuss these commercial methods here but explanations can be found on the company websites.

\section{Research methodology}

The case study method was used in this study as it is a useful method because it allows data to be examined at a micro level (Zainal, 2007). The advantages of this approach is that the examination of the data was conducted within the appropriate context (Y in, 2009). The detailed qualitative work that is allowed for in the case study method was explored in a real life situation and assisted in highlighting and understanding the complications that the real life environment adds. This would not have been possible in experimental or survey based research (Zainal, 2007). A disadvantage of using the method was that case studies allow for very little generalisation due to the small sample size; however, the objective of the research was not to be a broad all-encompassing study but rather to gain an in-depth understanding and provide a guideline to marketing managers.

The case site that was used for this study was The South African Gold Coin Exchange. (http://www.sagoldcoin.co.za/). This organisation has been trading for forty years, and is the largest of its kind in South Africa. Two executive and two non-executive board members were interviewed. In addition, eight senior executives were interviewed from various departments within the organisation. In total twelve senior managers and directors were personally interviewed, seven males and five females. Two were from the finance department, four from management, two from marketing, and one each from information technology, sales, human resources and retailing. Financial reports and management accounts dating back five years were used. The interviews with board members, financial department heads and executive committee members were designed to establish their perception of the brand, how they value the brand as a business resource, and for which purposes they would use a brand equity measurement. These managers had the relevant access to the financial data needed to calculate the value of the company's brand and were the decision makers who decided the major strategies of the firm.

Once the different brand equity valuation approaches were identified, mathematical models were used to apply the selected brand valuation approaches. Semi-structured interviews were also used to determine brand equity valuation objectives. Data were collected by reviewing the financial statements and management accounts of the case site as well as through the individual interviews conducted with the respondents. The data collected from the financial statements and management accounts were applied to the mathematical models as suggested by Abratt and Bick (2003) for each valuation approach.

\section{Results}

\section{Valuations of the South African Gold Coin Exchange brand}

Respondents were then taken through seven calculations that had been performed on the organisation and asked which method they would feel most comfortable using.

Seven brand valuation approaches were calculated as shown in Table 1. 
Table 1: Brand valuation approach calculation results

\begin{tabular}{|c|c|c|}
\hline Brand valuation approach & Formula & Result \\
\hline Accumulated cost model & Brand value $=\Sigma$ costs incurred to date less amortization & $\mathrm{R} 62,391,330$ \\
\hline $\begin{array}{l}\text { Replacement cost based on launching a } \\
\text { new brand }\end{array}$ & $\begin{array}{c}\text { Brand value }=\text { cost of launching the brand / probability of } \\
\text { success }\end{array}$ & $\mathrm{R} 102,412,780$ \\
\hline The residual method & $\begin{array}{c}\text { Brand value }=\text { market capitalization (or equity valuation) less } \\
\text { tangible assets and other identified intangible assets }\end{array}$ & R86,736,591 \\
\hline $\begin{array}{l}\text { Royalty relief method (using turnover as } \\
\text { a base) }\end{array}$ & $\begin{array}{c}\text { Brand value }=\text { royalty rate } \mathrm{x} \text { base } \mathrm{x}(1+\text { growth rate }) / \text { (Discount } \\
\text { Rate growth rate })\end{array}$ & $\mathrm{R} 66,927,778$ \\
\hline $\begin{array}{l}\text { Royalty relief method (using profits as a } \\
\text { base) }\end{array}$ & $\begin{array}{c}\text { Brand value }=\text { royalty rate } \mathrm{x} \text { base } \mathrm{x}(1+\text { growth rate }) / \text { (Discount } \\
\text { Rate growth rate })\end{array}$ & $\mathrm{R} 77,915,715$ \\
\hline Price premium method & $\begin{aligned} \text { Brand value }= & \text { price premium } \times \text { base } \times(1+\text { growth rate }) / \\
& \text { (discount rate }- \text { growth rate) }\end{aligned}$ & $\mathrm{R} 373,995,430$ \\
\hline Future earnings model & Brand value $=\Sigma$ discounted brand profit & $\mathrm{R} 111,953,398$ \\
\hline Discounted cash flows model & Brand value $=\Sigma$ discounted cash flows attributable to the brand & $\mathrm{R} 127,230,299$ \\
\hline
\end{tabular}

Respondents selected six out of the seven calculations, with future profits being selected four times and the residual method and price premium method being selected three times each. The replacement cost method received no responses. Only one respondent indicated that he was selecting the calculation purely based on the value; all other respondents indicated that the inputs in the formula were being considered and not the result of the calculation. As the calculations indicated, different brand valuation approaches provided different brand equity valuation results. Respondents indicated that two out of the seven approaches were preferred. The future profits and residual methods received more than six interviewee selections. The results confirmed that different brand equity valuation approaches would provide different brand equity valuation results. The Seven brand valuation approaches calculated are now discussed.

The cumulative cost approach calculation included the costs incurred to date and were used from 2008 up to, and including, 2012. All non-branded element costs were removed and the amounts amortised. $12 \%$ of respondents selected this model as one of their preferred methods and felt that although the formulation was relevant to marketing spend it was not forward looking and inputs were too limited. The replacement cost approach calculation included the cost to launch and was calculated as current costs and included all existing branded elements, advertising and current media holdings. The probability of success was placed at $10 \%$ : this is because recent studies have shown that newly launched brands suffer from high failure rates of $50 \%$ or more (Ogawa \& Piller, 2006), and potentially as high as $95 \%$ in the United States and $90 \%$ in Europe (Kotler $\&$ Keller, 2009). The replacement cost approach received no support from respondents whose comments included that it is not a fair reflection of brand value built up over time and that the probability of success was too subjective. The residual method approach calculation used an equity evaluation and was performed using the financial statements. Intangible assets were removed from the equity valuation and there were no other identifiable intangible assets. The residual method received a lot of support from respondents as they felt that this model was less subjective than any of the other approaches.
The royalty relief approach calculation used two calculations, one using net profit as the base value and $25 \%$ as the royalty rate; and the other using turnover as the base value and $5 \%$ as the royalty rate. The growth rate was determined by using a forecasted growth rate over a fiveyear period. Forecasts were provided for both the turnover and net profit growth calculations. The South African Gold Coin Exchange is a private company and as such the traditional method of calculating a discount rate using regression could not be performed. As per Damodaran (2008), finding similar companies listed on the stock exchange and using that firm's data to calculate a discount rate for the private firm is an acceptable method. The South African Gold Coin Exchange has a unique product and in an industry characterized by few players it was difficult to find a listed firm that mimicked The South African Gold Coin Exchange's performance. Financial institutions were ruled out due to their governance by financial and banking regulations. The gold price was ruled out due to a limited correlation between its influencers and that of the South African Gold Coin Exchange. The New Gold exchange traded fund was found to be a suitable measure as its response to market forces matched the South African Gold Coin Exchange closely. A regression was performed and a discount rate calculated. The discount rate was presented to the financial officer to ensure reliability, and was confirmed to be reliable.

The price premium approach calculation was calculated as per the description under the royalty relief approach. Net profit was used as the base value. To determine the price premium the premium charged on the sales of Krugerrands was used. Rare and collectable products were excluded as the majority of products sold by the South African Gold Coin Exchange are exclusively sold through the brand and as such there is no comparable non-branded product. Krugerrands are widely sold and in this study the Krugerrand sales by the South African Gold Coin Exchange were argued to be due to the brand association. The model received the support with respondents indicating that they were comfortable with this method due to their brand value definition: that it is the premium that a customer is willing to pay over a generic product. 
The future earnings approach calculation used net profit and was forecast for five years and discounted back to a present value. The percentage of future profits attributable to the brand was determined by considering the percentage of profits attributable to exclusive products. Krugerrands as such were excluded as customers could in future purchase these products from the South African Gold Coin Exchange's competitors. Only rare and collectable products that were exclusively sold by the case site were used as a percentage of total profit. This ensured reliability of future contributions by the brand representing current contributions. This approach was well supported by the respondents indicating that this would be a model of choice. Respondents commented that they felt comfortable with this approach since the brand value is a portion of future profits thus being able to add value in the future.

The discounted future cash flows approach calculation was determined by forecasting cash flows over the next five years and then discounting them back to a present value. The portion of future cash flows attributable to the brand was determined using the methodology as described under the future earnings approach. Discounted future cash flows did not receive as much support as expected.

Brand valuation calculations applied to the South African Gold Coin Exchange confirm that different brand valuation approaches will provide different brand valuation results. Respondents were more concerned about the inputs into the approach formulation than they were about the results. This is encouraging in terms of matching brand valuation approaches to brand valuation objectives.

\section{Valuation objectives}

The results indicated that respondents strongly believed that the approach they had selected matched their objectives. Respondents were more concerned about the structure of the formula of the approach than they were with the actual result. More than half of respondents said that it was important for a firm to differentiate it in order to stand out from competitors. They understood that a differential advantage could be created through a unique offering and by doing so it increased shareholder value. Respondents indicated that by representing the personality of the firm and positioning the overarching perception of the firm, the brand aligned business and internal culture with the external perception of the brand. This made the brand a valuable asset to the organisation. Respondents believed that brand equity was based on brand recall and recognition and that strong brand equity could increase sales and profits - and ultimately margins - which would add value to the business. The results confirmed that brand equity valuation objectives influence the selection of the brand equity valuation approaches.

Table 2 shows the objectives for brand valuation provided by respondents.

Table 2: Respondents' brand valuation objectives correlated with Salinas (2009) categorization

\begin{tabular}{|c|c|c|c|}
\hline & $\begin{array}{c}\text { Valuations for accounting } \\
\text { purposes }\end{array}$ & $\begin{array}{l}\text { Valuations for transactional } \\
\text { purposes }\end{array}$ & $\begin{array}{l}\text { Valuations for strategic brand } \\
\text { management purposes }\end{array}$ \\
\hline \multirow{5}{*}{$\begin{array}{c}\text { Respondents' } \\
\text { objectives for } \\
\text { performing a brand } \\
\text { valuation. }\end{array}$} & Listing on the stock exchange. & Selling the business. & $\begin{array}{l}\text { To use the brand value as a selling } \\
\text { tool. }\end{array}$ \\
\hline & Bringing partners into the business. & & Determine the brand's strength. \\
\hline & New market entry or diversification. & & Benchmarking. \\
\hline & Shareholder value calculation. & & Tracking the brand's growth. \\
\hline & $\begin{array}{l}\text { Putting the brand on the balance } \\
\text { sheet. }\end{array}$ & & $\begin{array}{l}\text { Use the value to build credibility in } \\
\text { the brand. }\end{array}$ \\
\hline
\end{tabular}

Results pertaining to brand valuation for accounting purposes showed a range of preferred approaches; the accumulated cost method, future profits method, residual method, royalty relief method and price premium method were all being selected an equal number of times for accounting objectives. Results for brand valuation for transactional purposes showed a strong preference for the residual method. Results pertaining to the brand valuation for strategic marketing management objectives showed a slight preference for the price premium method and the future profits method. Royalty relief and accumulated cost method showed moderate significance.

\section{Objectives and brand valuation selection method}

Respondents indicated that their objectives influenced their selection of the brand valuation approach. Only one respondent indicated that he would not change his valuation approach selected when asked to suggest a new objective. This is shown in Table 3. 
Table 3: Brand valuation method selected for different brand valuation objectives

\begin{tabular}{c|c|c}
\hline Brand valuation objective & Brand valuation method & Number of times selected \\
\hline To use the brand value as a selling tool & Royalty relief method & 1 \\
\hline Bring equity partners into the business & Accumulated cost method & 1 \\
\hline & Price premium method & 1 \\
\hline & Future profit method & 1 \\
\hline To track brand growth & Residual method & 1 \\
\hline & Accumulated cost method & 2 \\
\hline & Future profits method & 3 \\
\hline To determine brand strength & Integrated approach & 1 \\
\hline To sell the business & Discounted future cash flows method & 1 \\
\hline & Price premium method & 1 \\
\hline & Residual method & 4 \\
\hline Build brand credibility & Residual method & 1 \\
\hline To determine the company value & Price premium method & 1 \\
\hline To benchmark the brand & Discounted future cash flows method & 1 \\
\hline New market entry or diversification & Future profits method & 1 \\
\hline To put the brand on the balance sheet & Price premium method & 1 \\
\hline
\end{tabular}

Results show that different objectives led to the respondents preferring different brand valuation methods. This explains why there is a large discrepancy in the lowest brand value and the highest brand value in the case site.

\section{Conclusion}

Many different brand valuation approaches were reviewed. Seven approaches were applied to the SA Gold Coin Exchange, each providing a different brand equity valuation result and thereby confirming that different brand equity valuation approaches will provide different brand equity valuation results. It was observed from the respondents when selecting a brand valuation approach model they considered brand valuation objectives. A preference for an approach that has as little subjectivity as possible was strongly favoured. Not only were the approaches confirmed to have an influence on the brand valuation approach selection, but brand valuation approaches could clearly be categorized as suggested by Salinas (2009). Anyone looking at the brand equity valuation of an organisation must be aware of the fact that that valuation is one of many and this could vary depending on what method or approach was used.

\section{Recommendations}

Any organisation that wants to do a brand valuation should go through the process shown in Figure 1.

The first step in the process is to determine the objective of the brand valuation. This is an important first step as it determines which valuation methods are appropriate to achieve this objective. Ten major brand valuation objectives have been identified in this step. Should more than one brand valuation objective be selected, each brand valuation objective will need to have a brand valuation approach selected and considered solely for that specific objective. The second step in the process is to consider the brand valuation approach options available in each category. Figure 1 also lists the appropriate brand valuation techniques for each objective. Once a brand valuation approach has been selected the third step requires that the inputs of the specific brand valuation approach be inspected and evaluated based on two questions:

1) Do the elements or inputs to the calculation relate to my objective?

2) Is the information required to perform this calculation available and reliable?

Step 4 involves scrutinizing the data, the filters applied to it, the sources and the "purity" of the input relating to the objective. Ensure that the data does not contain elements that may skew results. For example in the accumulated cost approach the costs need to be removed of any marketing spend that does not relate to building the brand. For example a prize with no branding on it should not be included. Applying this filter to each input will ensure the reliability of the inputs. Finally step 5 entails performing the actual calculation.

This process will help managers with their decision making with regard to the appropriate brand valuation to use. This will depend largely on their brand valuation objectives and the availability of the required information needed for the relevant calculations (Hull, 2008). One thing is for sure. Various stakeholders of the organisation must not accept the first brand valuation that they are given by the management of an organisation. The method or approach used must be queried, other valuation approaches should be considered, as well as the objectives of the valuation. 
Step 1: Determine the Objectives of the calculation

\begin{tabular}{|c|c|c|c|c|c|c|c|c|c|}
\hline $\begin{array}{l}\text { Use the brand } \\
\text { value as a } \\
\text { selling tool }\end{array}$ & $\begin{array}{l}\text { Bring equity } \\
\text { partners into } \\
\text { the business }\end{array}$ & $\begin{array}{l}\text { Track brand } \\
\text { growth }\end{array}$ & $\begin{array}{l}\text { Determine } \\
\text { brand strength }\end{array}$ & $\begin{array}{l}\text { To sell the } \\
\text { business }\end{array}$ & $\begin{array}{l}\text { Build Brand } \\
\text { Credibility }\end{array}$ & $\begin{array}{l}\text { Detertnine } \\
\text { company } \\
\text { value }\end{array}$ & $\begin{array}{l}\text { To benchmark } \\
\text { the brand }\end{array}$ & $\begin{array}{l}\text { New market } \\
\text { entry or } \\
\text { diversification }\end{array}$ & $\begin{array}{l}\text { To put the } \\
\text { brand on the } \\
\text { balance sheet }\end{array}$ \\
\hline
\end{tabular}

Step 2: Consider the brand valuation approaches relevarit to the determined objective category

\begin{tabular}{|c|c|c|c|c|c|c|c|c|c|}
\hline $\begin{array}{l}\text { Use the } \\
\text { royalty relief } \\
\text { method }\end{array}$ & $\begin{array}{l}\text { Use either: } \\
\text { Accumulated } \\
\text { cost method; } \\
\text { Price premium } \\
\text { method; } \\
\text { Future profit } \\
\text { method; } \\
\text { Residual } \\
\text { method }\end{array}$ & $\begin{array}{l}\text { Use either; } \\
\text { Future profits } \\
\text { method; } \\
\text { Accumulated } \\
\text { cost method; } \\
\text { Integrated } \\
\text { approach; } \\
\text { Discounted } \\
\text { future cash } \\
\text { flows method }\end{array}$ & $\begin{array}{l}\text { Residual } \\
\text { method }\end{array}$ & $\begin{array}{l}\text { Use either; } \\
\text { Residual } \\
\text { method; } \\
\text { Price premium } \\
\text { method; } \\
\text { Discounted } \\
\text { future cash } \\
\text { flows method; } \\
\text { Future profits } \\
\text { method }\end{array}$ & $\begin{array}{l}\text { Price premium } \\
\text { method }\end{array}$ & $\begin{array}{l}\text { Use the } \\
\text { method that } \\
\text { provides the } \\
\text { highest value }\end{array}$ & $\begin{array}{l}\text { Royalty } \\
\text { Relief } \\
\text { method; } \\
\text { Price } \\
\text { preminm } \\
\text { method }\end{array}$ & $\begin{array}{l}\text { Royalty relief } \\
\text { method }\end{array}$ & $\begin{array}{l}\text { Price premium } \\
\text { method }\end{array}$ \\
\hline
\end{tabular}

Step 3: Consider the inputs of the approaches appropriate for the objective

Step 4: Ensure the credibility of the data

Step 5: Perform the calculation

Figure 1: Recommended brand valuation calculation process

\section{References}

Aaker, D.A. 1991. Managing brand equity: Capitalizing on the value of a brand name. New York: The Free Press.

Aaker, D. A. 2004. 'Leveraging the corporate brand', California Management Review, 46(3): 6-18.

Abratt, R. \& Bick, G. 2003. 'Valuing brands and brand equity: Pitfalls and processes', Journal of Applied Management and Entrepreneurship, 8(1): 21-39.

Amini, A., Darani, M., Afshani, M., \& Amini, Z. 2012. 'Effectiveness of marketing strategies and corporate image on brand equity as a sustainable competitive advantage', Interdisciplinary Journal of Contemporary Research in Business, 4(2): 192-205.

Balmer, J. M. T. \& Gray, E. R. 2003. 'Corporate brands: what are they? What of them?', European Journal of Marketing, 37(7): 972-997.

Barney, J. B. 1991. 'Firm resources and sustained competitive advantage", Journal of Management, 17(1): 99 120 .

Baumann, C., Gray, D. \& Mirzaei, A. 2011. 'Developing a new model for tracking brand equity as a measure of marketing effectiveness', The Marketing Review, 11(4): 323-336.

Bick, G.N.C. 2009. 'Increasing shareholder value through building customer and brand equity', Journal of Marketing Management, 25(1/2): 117-141.
Brownhill, I. 2012. 'Trust the brand', Training Journal, (May), pp. 42-45.

Catty, J.P. 2011. 'ISO 10668 and brand valuations: A summary for appraisers', Business Valuation Update, 17(4): $1-7$.

Christensen, H.K., Fahey, L. \& Srivastava, R.K. 2001. 'The resource-based view and marketing: The role of marketbased assets in gaining competitive advantage', Journal of Management, 27(6): 777-802.

Damodaran, A. 2008. Damodaran on valuation. New York: John Wiley and Son.

Doyle, P. 2001. 'Shareholder-value-based brand strategies", Brand Management, 9(1): 20-30.

Gerzema, J. 2009. 'The brand bubble', Marketing Research (Spring): 7-11.

Harris, F. \& Chernatony, L. 2001. 'Corporate branding and corporate brand performance', European Journal of Marketing, 35(3/4): 441-456.

Heitmann, M., Lehmann, D. R., Neslin, S. A. \& Stahl, F. 2012. "The impact of brand equity on customer acquisition, retention, and profit margin', Journal of Marketing, 76(4): 44-63. doi: $10.1509 / \mathrm{jm} .10 .0522$

Hull, J. 2008. 'How marketers should use brand valuation', Market Leader, Autumn: 51-55. 
Interbrand. 2004. Brand valuation. A chapter from Brands and branding, New York: Interbrand.

Kapferer, J.N. 1997. Strategic brand management. 2nd edition. London: Kogan Page.

Keller, K.L. 2013. Strategic brand management. 4th edition. Upper Saddle River, New Jersey, Prentice Hall.

Kotler, P. \& Keller, K.L. 2009. Marketing management. 13th edition. Upper Saddle River: Pearson Prentice Hall.

Leiser, M. 2004. 'Understanding brand's value: advancing brand equity tracking to brand equity management', Handbook of Business Strategy, 5(1): 216-222.

M'Zungu, S.D.M., Merrilees, B. \& Miller, D. 2010. 'Brand management to protect brand equity: A conceptual model', Journal of Brand Management, 17(8): 605-617. doi: $10.1057 / \mathrm{bm} .2010 .15$

Narayan, G. 2012. 'Brand valuation: A strategic tool for Business', Journal of Brand Management, 9(3):55-64

Ogawa, S. \& Piller, F.T. 2006. 'Reducing the risks of new product development', MIT Sloan Management Review, 47(2): $65-71$.

Otonkue, A.D.O., Edu, B.E. \& Ezak, E. 2010. 'Accounting for brands: Contemporary issues and alternative options', IUP Joumal of Brand Management, 71(2): 105-115.

Raggio, R.D. \& Leone, R.P. 2009. 'Drivers of brand value, estimation of brand value in pactice and use of brand valuation: Introduction to the special issue', Journal of Brand Management, 17(1): 1-5.

Salinas, G. 2009. The international brand valuation manual: A complete overview and analysis of brand valuation techniques, methodologies and applications. New York: Wiley.

Salinas, G. \& Ambler, T. 2009. 'A taxonomy of brand valuation practice: Methodologies and purposes', Journal of Brand Management, 17(1): 39-61.doi: 10.1057/bm.2009.14

Seetharaman, A., Bin Mohd Nadzir, Z. \& Gunalan, S. 2001. 'A conceptual study on brand valuation', Journal of Product and Brand Management, 10(4): 243-256.

Shamma, H.M. \& Hassan, S.S. 2011. 'Integrating product and corporate brand equity into total brand equity measurement', International Journal of Marketing Studies, 3(1): 11-20.

Simon, C.J. \& Sullivan, M.W. 1993. 'The measurement and determinants of brand equity: A financial approach', Marketing Science, 12(1): 28-52.

Smith, K.T., Smith, M. \& Wang, K. 2010. 'Does brand management of corporate reputation translate into higher market value?', Journal of Strategic Marketing, 18(3): 201 221.

Virvilaite, R. \& Jucaitytè, I. 2008. 'Brand valuation: Viewpoint of customer and company', Engineering Economics, 56(1):111-119.

Yeung, M. \& Ramasamy, B. 2008. 'Brand value and firm performance nexus: Further empirical evidence', Journal of Brand Management, 15(5): 322-335.

Yin, R. 2009. Case study research: Design and methods. Beverly Hills: SAGE Publications.

Zainal, Z. 2007. 'Case study as a research method'. Journal Kemanusiaan, 9: 1-5. 